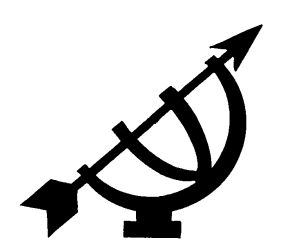

\title{
Rehabilitating the traitor in Taylor Caldwell's I, Judas
}

\author{
F. Hale \\ School of Ecclesiastical Sciences \\ Potchefstroom Campus \\ North-West University \\ POTCHEFSTROOM \\ E-mail: fh243@cam.ac.uk
}

\begin{abstract}
Rehabilitating the traitor in Taylor Caldwell's I, Judas

During the course of the previous century, authors from various genres attempted to clear the name of Judas Iscariot, or alternatively, tried to explain why he betrayed Jesus Christ. One of the most ambitious attempts at this was that of the wellknown British-American author Taylor Caldwell in her book called 'I, Judas' (1977). The strategy supporting Caldwell's partial exculpation of Judas is analysed against the background of various early descriptions of Judas. The conclusion is that Caldwell's excessively fertile literary imagination, combined with the encroachment of postbible traditions in this apparent first-person narrative of the accused disciple undermines the credibility of her alternative perception of Judas.
\end{abstract}

\section{Opsomming}

\section{Die rehabilitasie van die verraaier in Taylor Caldwell se verhaal I, Judas}

Gedurende die vorige eeu het skrywers in verskillende genres gepoog om Judas Iskariot se naam in ere te herstel, of om te verduidelik waarom hy Jesus Christus verraai het. Een van die mees ambisieuse pogings in hierdie verband was die bekende Brits-Amerikaanse skrywer Taylor Caldwell se boek 'I, Judas' (1977). Die strategie vir Caldwell se gedeeltelike verontskuldiging van Judas, word teen die agtergrond van verskeie vroeëre beskrywings van Judas geanaliseer. Daar word tot die gevolgtrekking gekom dat Caldwell se uitermate vrugbare literêre verbeelding, tesame met die indringing van na-bybelse tradisies in hierdie oënskynlik eerste-persoon verhaal van die 
beskuldigde dissipel, die geloofwaardigheid van haar alternatiewe persepsie van Judas ondermyn.

\section{Introduction}

In our multimedia modern societies, religious knowledge is often transmitted outside conventional religious texts. In Christendom, this is not entirely new. For many centuries, biblical narratives have undergone all manner of transmogrification at the hands of literary and visual artists. In their attempts to flesh out or otherwise elucidate what are often skeletal historical accounts, they have often been guilty of various forms of eisegesis. This long-standing tendency may have reached its apogee during the previous century when the cinema prompted overdramatisation of episodes in both the Old and New Testaments. Regardless of the medium, however, the licence which those who have exploited the Scriptures for artistic purposes have granted themselves has drawn mixed reactions ranging from encomiums for bringing what are in some cases obscure texts before the public eye to condemnation for altering beyond recognition accepted interpretations.

Twentieth-century literary history offers many lucid examples of how malleable biblical texts can be when subjected to the imaginations of creative writers. In the present article it is my purpose to examine how in her novel, I, Judas (1977), the British-American author Taylor Caldwell - one of the most popular Anglophone novelists of her era - attempted an ambitious if only partial exoneration of Judas Iscariot from the guilt he had borne. Judas Iscariot had endured this guilt for nearly two millennia in the New Testament, nearly that long in Christian dogma, and for many centuries in European literature and art. This analysis breaks new ground. Despite her prominence in the literary world and the fact that her fictional reconstructions of the evangelist Luke in Dear and glorious physician (1959) and the apostle Paul in Great lion of God (1970) won widespread acclaim, Caldwell has received only a small fraction of the critical attention bestowed on such contemporaries as Saul Bellow, Tony Morrison, John Updike, and Philip Roth. No detailed scholarly study of $I$, Judas is known to have been published to date. Furthermore, an analysis of Caldwell's treatment of Judas Iscariot is particularly timely, since in recent years scholarly attention has again focused on this disciple and uncanonical interpretations of his conduct. As will be discussed briefly below, the publication of a translation of the apparently gnostic Gospel of Judas has contributed to the renewal of international interest in him. It is not contended in this article, however, that Caldwell's interpretation of Judas is indebted to non-canonical 
accounts. Rather, principal aspects of $I$, Judas, especially the narrative strategy developed to exonerate the protagonist, will be examined against the backdrop of the history of the generally condemnatory representation of him. The great difficulty of offering plausible alternative interpretations of Judas, which are not transparently burdened by authorial licence and other weaknesses, will also be explored.

\section{Antecedent representations of Judas in church history}

In his commendable study Judas: images of the lost disciple, which remains the standard survey, Kim Paffenroth provided a useful introduction to the subject in European religious and intellectual history. He did not, however, include North American dimensions of it (Paffenroth, 1997).

In European literature and art, Judas Iscariot was almost invariably depicted negatively until the Enlightenment, when sporadic efforts were first undertaken to rehabilitate his image to varying degrees (Paffenroth, 1997). Dante Alighieri, for example, described him being eternally eaten by Lucifer at the centre of the Inferno, the ninth circle thereof eponymously labelled la Giudecca. Medieval European artists typically portrayed Judas with exaggerated Semitic facial features and surrounded by demons. In other manifestations of his alterity outside the familiar fold of the faithful, he was occasionally painted as a black man at a time when Christianity was regarded at least by its adherents in Europe - as primarily the religion of that continent's inhabitants, not as a faith for all the world's nations. There were exceptions, to be sure; the fifteenth century Florentine Dominican monk Fra Angelico put a golden halo above Judas in at least one of his paintings of the Last Supper - but in another, a depiction of the betrayal in the Garden of Gethsemane, Judas has a conspicuously dark halo (Morachiello, 1996:304).

Yet, historically the tradition was more varied. Within certain factions of the early church - especially those characterised by anti-materialistic Gnosticism, which denied the reality of the incarnation of God in human form and was, therefore, denounced as heretical Judas was lauded as an upright disciple of Jesus. Irenaeus, an influential second-century bishop of Lyon, lamented that some Gnostics regarded Judas as one who "recognized the truth and completed the mystery of betrayal" and accused them of having written a "fictitious history [...] which they style the Gospel of Judas" (Roberts \& Rambaut, 1868:113). That non-canonical work fell into oblivion, and its Greek text is not extant. Apparently the dissenting Christians 
who used it believed that Judas had played a pivotal role in the salvation of humanity by handing Jesus over to his enemies for crucifixion in accordance with God's plan, a notion which harmonised with the accounts in the New Testament.

In any case, the widely discussed discovery of gnostic manuscripts at Nag Hammadi on the east bank of the Nile during the 1940s left no doubt that some individuals in the second century discussed Judas with respect and not as one under the sway of Satan (Robinson, 1977:229-238). The announcement in 2006 that a manuscript (carbon-14 dated to between 220-340 AD) of a Coptic translation of the Greek text of the Gospel of Judas had been found renewed international interest in this non-canonical work. Like several modern fictional constructions of Judas, the early document suggested that the ostensibly betraying disciple had actually heeded a commandment by Jesus.

\section{The non-canonical Gospel of Judas}

In recent years the rediscovery of the non-canonical Gospel of Judas has reinvigorated scholarly consideration of this disciple. A spate of recent publications underscores the breadth of international interest in that disciple, his possible motivation, and his role in early Christian thought. Strictly speaking, it is not certain that a Coptic papyrus discovered in Egypt during the 1970s (or possibly as early as the 1950s in some accounts of the murky and confusing history of the unearthing of this manuscript and its subsequent meanderings as it was apparently sold and resold in Egypt and Europe) is in fact a translation of the Greek text of the Gospel of Judas, although that work is referred to therein. Nevertheless, many scholars believe that it is probably a rendering of that text, possibly an edited version thereof. If what has thus indirectly survived is at least a partly reliable mirror of the original text, the Gospel of Judas was probably written during the second century $A D$ and from a decidedly gnostic perspective. It assumes that readers have some awareness of other gospels of Jesus. The Gospel of Judas, or what has survived in fragments since its discovery approximately three decades ago, consists largely of dialogues (as do the other non-canonical gospels). In this case the dialogue was between Jesus and Judas, both of whom are portrayed as gnostic figures, or Jesus and his disciples in general. The master favours Judas among his disciples and initiates him into esoteric verities, which the other followers seem incapable of comprehending. Beyond that, Jesus requests Judas to turn him over to the Roman authorities as a step towards completion of his di- 
vinely ordained ministry. In so doing, Judas will be a liberator of Jesus, as in some dimensions of gnostic thought the physical body is a kind of spiritual prison, and release from it through death, frees the individual to a closer relationship with God. The fate of Judas is unclear in the gospel that bears his name. He tells Jesus that he has had a vision of being stoned by the other disciples, but this is not carried out. The interpretation of the divinity of Jesus and the role of Judas obviously deviates greatly from what had been proclaimed in the canonical gospels, as well as the Pauline and other epistles of the emerging New Testament.

The Coptic translation of the Gospel of Judas - if it is in fact that attracted not only scholarly but also popular interest, especially after the respected National Geographic Society in Washington published an English translation thereof in 2006. Renderings into other languages followed. Among Christian scholars of various denominational loyalties and theological hues, the Coptic text aroused considerable international interest, which yielded books by inter alia N.T. Wright (2006), Elaine Pagels and Karen L. King (2007), Bart D. Ehrman (2006), and Marvin W. Meyer (2007). One widely shared conclusion was that the Gospel of Judas shed more light on the gnostic mentality of the second century, than on either Jesus or Judas of the early first century. The canonical gospels continued to be respected as normative, and conventional beliefs about the betrayal of Jesus as a dastardly, self-serving act have remained largely intact. There is no compelling reason to believe that, when Caldwell was writing I, Judas in the 1970s, she was aware of any noncanonical accounts of the disciple in question. She appears to have relied largely on her imagination, though it is conceivable that she had read at least some of the modern literary works cited below.

\section{Antecedent modern literary attempts to exonerate Judas}

Caldwell was by no means the first literary artist to attempt either a full or partial rehabilitation of Judas Iscariot. Among twentieth-century novelists, one finds a succession of arguably failed efforts in revisionist versions of the canonical accounts of Jesus. The iconoclastic Irish writer George Moore's The brook Kerith (1916), was one noteworthy thrust in this direction; a few decades later Nikos Kazantzakis, writing from a post-orthodox Greek perspective, tried in The Greek Passion (1954) and The last temptation of Christ (1955), as did Marcel Pagnol in Judas (1955). Within the realm of English li- 
terature, one can also point to such works as Robert Graves's King Jesus (1946).

\section{Sanitising and denigrating Judas}

In brief, I, Judas is presented as a "diary" (though it hardly reads like one) written by the man whom the Christian tradition from the outset has regarded as the arch-traitor. A zealot who yearns for Jewish independence from the Roman Empire, he longs for a messiah who will galvanise a military campaign to expel the occupants of his homeland. At the age of 29 , this son of a moderately wealthy Pharisee in Jerusalem is commissioned by leaders of the Sanhedrin to investigate John the Baptist, whom they fear may be attracting a following which will pose a threat to their cushy, collaborationist arrangement with Pontius Pilate. While carrying out this task, Judas witnesses the baptism of Jesus, whom he comes to regard as the one to spearhead the long-awaited revolt. Judas is called to become one of the Twelve and faithfully follows the Master. Only gradually does he accept the apolitical nature of the kingdom of God which Jesus proclaims. Yet, he never completely sheds his dream of national liberation from Rome. After the triumphal entry of Jesus into Jerusalem, the dastardly high priests Caiaphas and Annas, who along with other collaborationist Sadducees regard this as a threat to public stability and fear a Roman crackdown should a popular uprising of any sort ensue, pressure Judas into assisting in bringing Jesus to trial. He reluctantly cooperates after being assured that the Master would not suffer great harm, and he believes that bringing matters to such a head would somehow contribute to the movement, which he still believes will become a reality. After realising that he has been exploited and that Jesus would be executed, Judas commits suicide while continuing to profess his almost total innocence.

In embellishing the biblical record of Judas Iscariot, Caldwell not only absolved him of the Satanic motives ascribed to him by Scripture and tradition for his ostensible betrayal of Jesus, but also granted herself licence both to sanitise and pejorate the man in other ways. Among the most obvious examples of her moral elevation of him, she challenges the Johannine accusation of his pilfering from the common purse of the Twelve (John 12:6). By his own account, Judas is a generous soul whose moral standards, apart from his sex drive (which will be discussed shortly), were impeccable. Far from being an avaricious soul, he recounts that in response to the Master's admonition he "gave generously for alms to the poor, knowing how he felt about those with much giving much" 
(Caldwell, 1977:204). This benign characterisation is poles apart from not only the predominant representations of Judas in nearly two centuries of Christian tradition, but also that of modern New Testament scholarship (O'Day, 1995:702; Whitacre, 1999:300-301). J. Ramsay Michaels (2010:669) spoke for many scholars in his 2010 commentary on the Gospel of John:

The blunt characterization of Judas as one who said what he said 'not because it mattered to him about the poor, but because he was a thief', evokes both 'the thief' in Jesus' earlier discourse about shepherds and sheep (10:2, 8, 10), and at the same time the 'hirelings' to whom 'it does not matter' ... about the sheep.

In short, Judas is not the typical well-meaning (if sometimes uninformed) disciple or potential disciple questioning the teacher. ... His motives are far more sinister, and his abrupt question is conspicuously not introduced by 'Lord' or 'Rabbi'.

In other respects, which lie completely in the realm of authorial imagination and have no anchoring in the New Testament, Caldwell underscores the moral fallibility of her protagonist. By the 1970s authors of biblical novels no longer universally regarded explicit sexual conduct as a taboo subject. The normal libido of Caldwell's Judas comes to the fore twice. In the fifth chapter, he impregnates his hitherto virginal, fifteen year old fiancée Rachel - even though he has already become one of the Twelve. He informs her that his discipleship prevents him from adopting a matrimonial life (Caldwell, 1977:90). In a more fantastic scene, Judas and a female follower of Jesus who serves as a maid to Claudia Proculla, the wife of Pontius Pilate, have intercourse in a supposedly private room in the procurator's Jerusalem residence. Almost immediately thereafter, Pilate informs him that their activity has been observed through peepholes in the ceiling. "You think Rome corrupt, then what of you, my pious friend," declares the voyeuristic Roman, "who speaks loftily of his God and seduces innocent maidens?" (Caldwell, 1977:263.)

\section{The Achilles' heel of zealotry}

A scarlet thread running through the text which explains more than any other the motivation behind Judas's willingness to cooperate with the Sanhedrin is his involvement in the Zealot movement. His intense yearning for national liberation from the Roman Empire declines only marginally, as he gradually accepts the fact that Jesus was not a militant revolutionary with a political agenda. Even after committing himself to the cause of moral and spiritual renewal, and 
accepting Jesus's frequently repeated message that He has come for the salvation of Jews and Gentiles alike, Judas lives in the hope that somehow the shackles of Rome would be cast off. This colours his conduct during the final week in Jerusalem. Nowhere in his narrative is there the slightest hint of apocalyptic expectation, which would have rendered a political independence movement irrelevant.

The crowning corroboration of this weakness as the crux of Judas's undoing comes from the mouth of Jesus. At the Last Supper, He responds to Peter's query about who the betrayer would be:

Let me tell you ... it could have been any of you. But none of you, with all your frailties, was captivated by your own desires, save one. I knew him immediately by his burning obsession. He wanted not fame, nor money, but to live in a dead tradition, and conquer another people. Even now, he does not realize that a Roman life is as dear to God as a Judean's. (Caldwell, 1977: 281.)

Only at the Last Supper does Judas discover that his status among the Twelve has declined. "Usually I sat in the second post of honor, at Jesus' right, while Peter was at his left," he relates. However, upon arriving late because of a meeting with his Sadducee handlers, Judas notices "with a sickening in my stomach, that Peter had usurped my customary place, and John was in Peter's position ..." . This unsubtle foreshadowing is accompanied by a gesture by Jesus which underscores the link to zealotry: the Master demotes him to sitting next to Simon Zelotes (Caldwell, 1977:275).

\section{The question of fidelity to Scripture}

$I$, Judas is a curious amalgam, which incorporates inter alia quotations from the King James Version of the Bible, Roman Catholic traditions, and much authorial licence in dealing with Scripture. A detailed consideration of Caldwell's departures from strict adherence to the canonical accounts of Jesus lies outside the scope of the present article. Apart from the character of Judas, representative examples of her free rein include reshuffling some of the chronological order of events; deconstructing the Sermon on the Mount by distributing teachings contained therein to various parts of her narrative; making Mary Magdalene the sister of Martha and Lazarus; describing the two men who were crucified alongside Jesus as followers who had turned against Him in disillusionment, after it became clear that He was not a political messiah; casting bar-Abbas 
as another disaffected disciple of Jesus; and ascribing to Gamaliel a significant degree of interest in and respect for Jesus.

To be sure, many other twentieth-century novelists who developed biblical themes granted themselves licence to augment the narratives found in the gospels, the Pentateuch, and other sections of Scripture. In the 1950s, when Caldwell was beginning to write her major novels about New Testament themes, they varied in both their attitudes towards this kind of freedom and the degree to which they indulged in it. In a particularly useful discussion of "fidelity to the text" in his contemporary study of The biblical Novel, Arnold D. Ehlert quoted numerous writers of that era who had adopted standards too stringent for Caldwell to meet. Florence M. Bauer, for example, the author of such works as Abram son of Terah, Behold your king and Daughter of Nazareth, insisted that it was inadmissible to take "liberties with the actual Bible text, except to modernise the English after consulting more than eight modern translations". On the other hand, she regarded it as defensible to supplement the canonical texts with imaginary narrative and dialogue. Similarly, Margaret Cate, author of Without a sword, believed that it was permissible, indeed virtually inevitable, "to telescope into a brief period of time events which were widely separated", but professed that she would not "put imaginary words into the mouths of historical characters" (Ehlert, 1960:4-5).

\section{The underlying premise of a first-person narrative}

Given the dearth of first-century sources for information about Judas, other than the snippets in the New Testament, novelists who have ventured to write about him have employed a variety of means to justify use of their imaginations to flesh out their narratives. Caldwell resorted to a lost but rediscovered source device which would subsequently be used by Morley Callaghan in $A$ time for Judas (1983) and Trevor Steele in Kaj staros tre alte (2006). In her case, as explained in a three-page foreword, after the renowned library at Alexandria was burnt in AD 500 a Christian Egyptian monk who bore the curious name "Iberias" discovered in its ruins "a partly charred manuscript, on durable Egyptian parchment". Perusing it "by candlelight or by the light of a smoking oil lamp", he found that it had been written "in highly polished Greek with some extrapolations in erudite Latin". Iberias concluded that it was therefore the work of "a gentleman of education". Its author was none other than Judas Iscariot, whose father was "a rich and powerful Pharisee Jew" in Jerusalem who also owned small palaces in Alexandria and Cairo. The 
Egyptian monk was shocked to learn from the text that the man whom both the canonical gospels and ecclesiastical tradition had described as an impoverished thief and despicable arch-traitor was a faithful follower of Jesus who had surrendered a comfortable lifestyle to take on the yoke of Christian discipleship and had borne it diligently. So revolutionary was the ostensible truth thereby revealed to lberias that he dared not reveal it to his less intellectually inclined confrères. Only on his deathbed did he entrust it to a young colleague, thus beginning nearly 1500 years of transmission of this secret manuscript, which eventually came into the possession of a German family. How and why it was published is not stated; instead, Caldwell merely asks readers to believe that "the manuscript has just been revealed by a member of that German family to whom it was returned. It has been carefully translated" (Caldwell, 1977:vii-ix).

That virtually all of this rationale lacks plausibility is obvious. Perhaps most evidently, the very existence of such a detailed account, which carries events up to the suicide of Judas, is arguably preposterous and the details of its discovery in Alexandria also test the limits of credulousness. What is particularly significant in the history of popular Christian literature, however, and will be explored below is how Caldwell's attempt to provide an alternative explanation for Judas Iscariot's conduct related to other such efforts to rehabilitate him while at the same time preserving much of the detail from the canonical gospels and upholding an orthodox view of Jesus Christ as the incarnation of God.

\section{Limits of Caldwell's research and catholic perspective}

In crafting what is essentially a historical novel posing as a firstperson account, Caldwell evinced a detailed grasp of numerous aspects of her subject. She evidently conducted extensive research into intertestamental Judaism and the history of the Roman Empire in the first century. There were, however, gaps in her knowledge of Roman rule. "They had brought peace to the world," observes Judas, "and they even had a name for it, the Pax Romana" (Caldwell, 1977:220). This attempt at didactic embedding in the text is an anachronism which, to be sure, flaws many other historic novels and non-fictional works about the first-century Mediterranean world. In fact, far from being ancient parlance the term Pax Romana is a historiographical construct put forth by Edward Gibbon in the initial volume of his book The history of the rise and fall of the Roman Empire (1776) to designate two centuries of peace ending in AD 180. He credited three emperors of the Nervan-Antonian dynasty, which 
ruled the Empire from AD 96 until AD 192, and involved the so-called "five good emperors" (Nerva, Trajan, Hadrian, Antonius Pius, and Marcus Aurelius) with ruling beneficently in their post-expansionist realm.

By every honourable expedient they invited the friendship of the barbarians; and endeavoured to convince mankind, that the Roman power, raised above the temptation of conquest, was actuated only by the love of order and justice.

To be sure, it came at a price: "The terror of the Roman arms added weight and dignity to the moderation of the emperors. They preserved peace by a constant preparation for war," granted Gibbon (1776:8-9). Certain other details reveal the limits of Caldwell's research and a lack of sophistication about New Testament scholarship. To cite but one illustrative example, apparently she accepted uncritically the tradition that the author of the Gospel of Matthew was the disciple and former tax collector of that name, while there is a corresponding identity of the "beloved disciple" and the fourth canonical evangelist. In the narrative, both he and John are repeatedly described as recording events and called "chroniclers" who were "forever scribbling, the Lord only knows what". Jesus himself knows; he tells them, "You, John, and you, Matthew, shall one day send your message to the four corners of the earth." (Caldwell, 1977:139.)

In places, moreover, the present encroaches on the past. Caldwell could not resist the temptation to use the sympathetic Pharisee Nicodemus as a spokesman for her conservative political agenda. In one of the oddest sections of the narrative, the sagacious Nicodemus, conversing with Judas and other disciples in the Temple, responds to their query about how to discern the weakening of a people's "character": "When they give over to government ... those duties which they should be pleased to perform themselves," he pronounces.

When they are told they will be fed and sheltered even when they won't work, when they are promised security from the cradle to the grave, when they are told the state will take over the supervision of their children and say what schooling they should receive and where. When they are told all these things and supinely accept them. (Caldwell, 1977:33.)

This is little more than a transparent diatribe against the twentiethcentury welfare state. 
Furthermore, parts of Judas's purported account read like they flowed from the pen of a latter-day Roman Catholic. Several of these relate to Mary, the mother of Jesus. In the narrative of the wedding feast at Cana, the Galilean disciple Andrew mentions Joseph, Simon, Jude, and James as the "brothers" of Jesus but for some reason, which is unnecessary to the plot, seems compelled to explain that they were actually "cousins" (Caldwell, 1977:99). This clearly smacks of defensiveness against criticism of the Catholic doctrine of the perpetual virginity of Mary, a tradition which was found in second-century Christian texts and certainly became widespread by the fourth century. It went largely unchallenged until the time of the protestant Reformation (and even then Martin Luther accepted it), but by the time Caldwell wrote, belief in the "ever virgin" Mary was under attack. In any case, Judas interviews Mary in Nazareth and describes here as "completely without guile or artifice", and a "saintly figure" who since the death of her husband Joseph had "lived on gloriously" (Caldwell, 1977:116, 119, 122). Turning to the Church of Rome as a permanent religious body, and with no hint of an eschatological dimension in early Christianity, Jesus calls the builder of "a church that shall never die" (Caldwell, 1977:139) and tells Judah that "Rome shall carry God's message to the distant corners of the earth" (Caldwell, 1977:220). To Judas, Peter is the "keeper of the keys" (Caldwell, 1977:273). At the Last Supper, what is said about foot-washing is embellished; Jesus informs Peter "those that come after you shall make a tradition of this" (Caldwell, 1977:279).

\section{The foundational construction of Judas}

Like virtually everyone else who has sought to construct Judas in fictional dress, Caldwell was compelled to employ her imagination liberally. His familial roots in Kerioth in Judea are mentioned but subordinated to his own social status in Jerusalem. Judas, who prefers the Hebraic form of his name (Judah) to the familiar Hellenised one, discloses in the first chapter that he is the scion of a "noble Judean family" and a descendant of David, has visited Rome, has studied under the eminent Pharisaic rabbi Gamaliel (who is a friend of his father), and in harmony with his religious convictions and standing in the community, views condescendingly the Amharetzin, the "humble peasants and shopkeepers ... whom no decent Pharisee or Sadducee would so much spit at" (Caldwell, 1977:1, 5, 9, 13, 16). But looming above all of these attributes in its significance to the interpretation of his relationship to Jesus is his zeal for national independence. "How can any Jew rest while the invader still stalks 
his land!" Judas declares in his first sentence. "My own heart is aflame" (Caldwell, 1977:1). His desire to cast off the yoke of Roman imperialism colours his perception of virtually everything, and particularly his expectations of the Messiah, in his narrative from cover to cover.

This comes to the fore when the young, Pharisaically-trained patriot is summoned at the outset of his tale to meet High Priest Caiaphas and others near the Temple. Their conversation underscores the older men's nervousness about Roman resolve to oppress severely any perceived challenges to imperial hegemony. Religious freedom, the final remnant of national independence, would cease. Caiaphas assures the hot-headed Judas that the Romans "will not interfere with Jewish worship so long as the people remain orderly and pay their taxes", while Gamaliel, who is also present, warns that in the event of even a minor insurrection, "The roads would soon be clogged with Roman troops from Syria and Egypt" (Caldwell, 1977:8, 11). Such admonitions do not cool Judas's ardour for national liberation, and his dialogue with the head of the Sanhedrin reveals the incompatibility of their respective messianic expectations. "We will know him by his works", insists Judas. Alluding ambiguously to "the Prophets", he professes, "How beautiful he is, ... the Messiah King who shall arise from the House of Judah. He will gird up his loins and advance to do battle with his enemies and man kings shall be slain." (Caldwell, 1977:11.) However, its appearance to the contrary, this is not a specific quotation from any of the prophetic works of the Hebrew Scriptures, but is taken from the targumim, the loose Aramaic translation thereof. Whether Caldwell was aware of this and where she derived this is impossible to know. At any rate, the "startled" Gamaliel counters by drawing on another, more specific, strand of prophetic tradition:

I see a different Messiah, born out of God's love for his people, and hating no man. $\mathrm{He}$ is the Prince of Peace, the Wise Counselor foreseen by the prophet Isaiah and so many others.

This elderly Pharisee adds:

Has it occurred to you, Judah-bar-Simon, that the Messiah you visualize is not sent to restore Israel to any temporal glory, but to redeem us from our sins? Is he not the Righteous One promised by Jeremiah? (Caldwell, 1977:11, 12.)

Against the backdrop of these divergent expectations and, especially in the minds of the Jewish elders, fears of would-be messiahs prompting harsh Roman responses, Caiaphas and Annas 
recruit Judas to undertake the "very critical mission" of investigating John the Baptist, whom the former High Priest describes as "an Essene, ... a fanatical leader of a fanatical sect from the monastery at Qamram by the Dead Sea". The ascetic John, he adds, "preaches that Jews should deny tribute to Rome, and drive out the tax collectors. This will not sit well with Pilate." (Caldwell, 1977:13-14.) Although Judas regards the Sanhedrin as little more than a collaborationist body dominated by Sadducees with whom he has no sympathy, he accepts this assignment in the hope that it will provide an "opportunity to seek out the Messiah wherever he was" (Caldwell, 1977:16).

\section{The discipleship of Judas}

That Judas regards himself as not only a faithful but a prominent and favoured disciple who, to a greater degree than the others in Jesus's inner circle of followers, comprehends his seemingly paradoxical teachings, is stressed. Two-thirds of the way through his narrative, he reports how in a conversation with Mary Magdalene, who informs him that she has reported his "sly ways" to Jesus, he replies, "I am one of the Twelve, handpicked by him, and sit next to him in the fellowship of our councils. Only Peter takes precedence over me." (Caldwell, 1977:226.) On the other hand, he acknowledges earlier in his narrative that because they misunderstood his "patriotism", "most of the [other] disciples considered me an unbeliever" (Caldwell, 1977:155).

Nevertheless, Judas presses ahead, remaining (not least in his own perception) loyal to the Master and testifies to his Messiahship. Less than a week before the crucifixion, he declares to Lazarus in Bethany,

Jesus ... is the universal man, the first and perhaps the only one, whereas his ancestor David epitomized the worldly man, with all his faults and frailties. In this way we are minded of Jesus' perfection as a man even as we are cognizant of the other's imperfections. (Caldwell, 1977:11.)

Fully conscious of his own yielding to sexual desires, Judas further comments to his host, "In this perfection he expressed his love for all, undiluted by any love of family or of woman" (Caldwell, 1977: 240). After entering Jerusalem, Judas earnestly explains the central thrust of the messianic message to Caiaphas, denying that it has a nationalistic or other political dimension: "He asks nothing of Israel but that it be repentant, and he offers salvation and everlasting life." 
When this fails to convince the High Priest, Judas pleads anew: "His is truly God's voice. ... Listen to Him, and Israel's troubles will vanish." (Caldwell, 1977:242, 245.)

Rarely one to eschew redundancy in his narrative, Judas concludes it with an account of his activities immediately after the crucifixion. In his segment, he coincidentally encounters bar-Abbas in an abandoned warehouse adjacent to the Garden of Gethsemane. Judas defends himself in a lengthy speech after bar-Abbas accuses him of betraying the Master. Judas explains his motivation for doing so; he fears that "unless I corrected this misconception before the others condemned me out of their envy because of the place I held with him" the world would remember him as a betrayer (Caldwell, 1977:323-324). "I left my house and my mother and my estates for him", he relates of his attraction to Jesus. "I followed him and exulted in him, and his words were as sweet as the juice of a pomegranate, and as living as honey and as fulfilling as milk and manna, and as tender as the flesh of the date." Judas acknowledges that he "doubted at first", because Jesus did not match his messianic expectations. His self-esteem and his faithfulness to Jesus went in tandem, he discloses:

None loved him as I loved him. None who followed him was as

I, a Pharisee of a noble family, a man of wealth and gold, honored in the holy places. The others were miserable people of no learning and family. (Caldwell, 1977:324-325.)

\section{The rhetorical strategy of exoneration}

Caldwell's partial exoneration of Judas proceeds primarily from two complementary thematic Leitmotiv, namely Judas's repeated insistence that he was a faithful disciple who had absolutely no personal incentive to betray the Master and Jesus's recurrent statements that Judas's conduct was all foreordained. Rather too frequently and too explicitly to suggest anything other than rhetorical self-exoneration, Judas asserts the depth and sincerity of his fidelity to Jesus. This leitmotiv begins while Judas longs for Him to be a militant liberator of the Jewish people from the Roman Empire and continues after Judas gradually accepts the fact that the Messiah will establish a spiritual kingdom, not a national or political realm. Several key examples will illustrate Caldwell's employment (and, arguably, excessive use) of this self-assertion.

In the fourteenth chapter ("The Plot"), Judas professes to Mary Magdalene that Jesus is "the universal man" and stresses His 
"perfection as a man". He also assures her that he does not need to be reminded of the Master's love for him (Caldwell, 1977:240). In a meeting immediately thereafter with Caiaphas and Annas, Judas defends Jesus as One who "would not for a moment consider any temporal advantage". Instead, he informs these high priests, "He asks nothing of Israel but that it be repentant, and He offers salvation and everlasting life" (Caldwell, 1977:242). In a subsequent discussion with Gamaliel about service to Caiaphas and Annas, Judas complains that he had been "but a pawn", a lament which the elderly Pharisee confirms (Caldwell, 1977:245). When Judas very reluctantly agrees to cooperate with the High Priests to bring Jesus to trial, he states that he would do it only "for His sake, and for Israel". Describing his own reaction outside the dialogue, Judas professes, "I shrank at even appearing to betray him." (Caldwell, 1977:247.)

The recurrent theme continues during the final week. In a meeting with Pontius Pilate, Judas (who subsequently pleads in his account that he "had no wish to play the betrayer, even innocently") defends the spiritual character of the anticipated kingdom (Caldwell, 1977: 253-254). He is, moreover, confident that the procurator meant Jesus "no harm" (Caldwell, 1977:260). In recounting the Last Supper, Judas declares that he "cherished" the Master (Caldwell, 1977: 275), and on that occasion he vigorously assures Jesus that he loves him (Caldwell, 1977:280). Later that night, after kissing Jesus in the Garden of Gethsemane, he whispers to Him, "This is no betrayal, Master." (Caldwell, 1977:285.) When Jesus is tried before Caiaphas, Judas protests about the irregularity and injustice of the proceedings, and in his written commentary afterward he describes it as a "mockery" (Caldwell, 1977:287, 295). He then tries to decline the 30 pieces of silver and writes, "I could have died in my shame, for I had committed no betrayal, despite what it looked." (Caldwell, 1977:296.) After Jesus is taken before Pilate and the procurator asks why he has "betrayed this innocent man?", Judas exclaims, "I only wanted him to declare himself ... that is all I ever wanted" (Caldwell, 1977:301).

Judas marshals another authoritative figure in his partial exoneration of himself. After the crucifixion, Mary the mother of Jesus, seeks to console him. "Had it not been you ... it would have been another. He knew this" (Caldwell, 1977:316-317).

At nearly as many points in the narrative, one finds embedded in the text either hints or direct statements by Jesus indicating that the role of Judas in the passion story was divinely foreordained. The initial 
foreshadowing of Jesus's awareness of this part occurs in the fourth chapter, "Jesus", during the first encounter of the two men. In Judas's account, he professes "with emotion", "You are indeed the Son of God." The reaction of Jesus is a "sad smile, as if he knew something that I didn't know" (Caldwell, 1977:75). The precise nature of this imponderable begins to take shape four chapters later when Jesus calls his inner circle of twelve disciples and modifies some of their names. Judas is not pleased that "Iskerioth", or in the Greek style, "Iscariot" is added to his personal name, because he believes the consonants "SKR" are a symbol for "betrayer". Jesus dismisses the implied protest cryptically: "You have not chosen me. But I have chosen each of you." (Caldwell, 1977:137.) On the same occasion, Jesus provides more hints of foreboding, though without reducing the unknown factor, by telling Judas that he "shall be my vehicle on the road to life everlasting" (Caldwell, 1977:139). When the two discuss the question of security and the possibility of early death, Jesus informs him, "You will know about my going before any of the others, Judah", adding words that underscore the foreordained aspect of his death. He states that "No man taketh my life. I die to fulfill the ancient prophecy and show the world that life is everlasting." (Caldwell, 1977:145.)

As Jesus and the Twelve draw nearer to Jerusalem and the Easter event, Jesus implies that in practical terms no betrayal is necessary. Noticing that Judas is apprehensive about the possibility of his Master falling into the hands of the occupation forces, Jesus asks him rhetorically, "Do you think for a moment that they know not where to take me?" (Caldwell, 1977:225.) On the evening of the Last Supper, Jesus informs Judas that his own death is the will of the Father, but He states that this is a necessity with a glorious purpose: "Only by dying can the Son of Man show there is no death." (Caldwell, 1977:269.) The issue of the foreordaining of the betrayal follows at that event. In an enhancement of Scripture, Jesus informs the Twelve: "I chose him well, for I saw even then the seeds of betrayal in him." He adds that "it had to be done so that man will know till the end of time to what purpose I was sent. For in my death, they will remember my life" (Caldwell, 1977:277). In a subsequent private comment to Judas, which embellishes John 13:27 in a way which reinforces the aspect of foreordainment, He admonishes him to "act with dispatch, so that the prophecy of old will be fulfilled" (Caldwell, 1977:280). 


\section{Fingering the real betrayer}

While Caldwell leaves no doubt that the principal villains in the plot against Jesus were Annas and Caiaphas, she lays the guilt of betrayal at the doorstep of Joshua bar-Abbas. This firebrand, whose enthusiasm for armed revolt against Roman hegemony matched that of Judas, was, like him, a follower of Jesus - though never among the Twelve. Unlike Judas, however, bar-Abbas never experienced a metanoia which altered his conviction that the messiah must be a political liberator. Consequently, he became disillusioned with the peaceful and decidedly unnationalistic message of Jesus and eventually leaves. What is eventually revealed near the conclusion of the narrative is that after doing so he became an informant, reporting every movement of Jesus and the Twelve to the Sanhedrin.

Not until the nocturnal trial of Jesus before that body does Judas become aware of bar-Abbas's treachery. Called as a witness for the prosecution, bar-Abbas casts a "scornful glance" at Judas but does "not dare look at the Master". His testimony is perjury; he declares that he remained a follower of Jesus "until I saw that he led the Jews to insurrection". In further fabrications, bar-Abbas testifies that Jesus claimed that God begat him "in a wave of clouds" and that in Galilee "the crowd was so aroused that it stampeded among great shouting, and would have crowned him King then and there had he not drawn back when he observed some soldiers in the crowd". The disingenuousness of this prompts Judas to think, "How some men twist the truth to their own evil purpose." (Caldwell, 1977:290.)

As indicated above, Judas and bar-Abbas meet again shortly after the crucifixion but before the resurrection of Jesus. That the real betrayer is bar-Abbas is again underscored. Judas repeatedly calls him a "traitor" and, revealing that he himself never completely shed his conviction that the messiah would be a national liberator, insists that "the insurrection died with Christ, and you helped to kill it with your treachery". Bar-Abbas reveals that he never regarded Jesus as "more than a magician who could hypnotize the gullible with this alien gift of his. Had he been the Messiah, he would not have left us when we wanted him for our King." (Caldwell, 1977:323, 324.)

\section{Conclusion: the virtual impossibility of the endeavour}

One does not indulge in gratuitous cynicism by suggesting that one of the greatest merits of $I$, Judas is unintended. Caldwell's novel inadvertently demonstrates the great difficulty or indeed the impossibility of writing an account of Judas Iscariot which is not only 
convincing in the eyes of readers who are unfamiliar with the canonical gospels, but will be plausible to those who are - especially those with even a moderate degree of scriptural sophistication. After all, the underlying premise that Judas kept a diary (or wrote a narrative that reads like a first-person novel) immediately founders on the rocks of incredibility. Even if the narrative were not burdened with elements that are clearly more in accord with subsequent Roman Catholic tradition than what a Judean would have penned around $A D 30$ and various clues that indicate its twentieth-century origins, such as the disparaging remarks about the welfare state, there is little reason to believe that a disciple would have kept the detailed account, including extensive quotations, which comprise much of the text. Going a step further, there is no reason whatsoever to accept that he would have had time to write the last few chapters which deal with the trial of Jesus, the crucifixion, and subsequent events before committing suicide before the Resurrection took place. It simply could not happen.

Beyond this fundamental narratorial flaw, Caldwell's case is undermined by the fact that much of it transparently rests on her literary imagination, not on a first-century source. With such scant information about Judas in the New Testament, in chapter after chapter she was compelled to flesh out her account with conversations that either embellish canonical texts (especially sayings of Jesus), or are completely unknown in the Gospels. Both of the previously discussed Leitmotivs relating to, respectively, Judas's professions of his innocence and the statements of Jesus that suggest that Judas's actions were foreordained, fall into this category. They are clearly fiction, and they cannot be expected to change the minds of many readers who know the New Testament. Caldwell's imagination and in places noteworthy research are impressive, but in the end one must conclude that they reinforce the conviction that we probably cannot know more about the mind of Judas Iscariot than the smidgens of information provided in the Gospels. I, Judas is thought-provoking, but not always for the reasons Caldwell no doubt intended. Mysteries, it seems, will always envelope the betrayal of Jesus Christ.

\section{List of references}

CALDWELL, T. 1959. Dear and glorious physician. Garden City: Doubleday.

CALDWELL, T. 1970. Great lion of God. Garden City: Doubleday.

CALDWELL, T. 1977. I, Judas. New York: Atheneum Publishers.

EHLERT, A.D. 1960. The biblical novel: a checklist with an introductory essay. Anaheim: $\mathrm{BCH}$ Publications. 
EHRMAN, B.D. 2006. The lost gospel of Judas Iscariot: a new look at betrayer and betrayed. Oxford: Oxford University Press.

GIBBON, E. 1776. The history of the decline and fall of the Roman Empire. Vol. 1. London: Strahan \& Cadell.

MEYER, M.W. 2007. Judas: the definitive collection of gospels and legends about the infamous apostle of Jesus. New York: HarperCollins.

MICHAELS, J.R. 2010. The Gospel of John. Grand Rapids: Eerdmans .

MORACHIELLO, P. 1996. Fra Angelico: the San Marco frescoes. London: Thames \& Hudson.

O'DAY, G.R. 1995. The new interpreters Bible. Vol. 9: The Gospel of John.

PAFFENROTH, K. 1997. Judas: images of the lost disciple. Louisville: Westminster John Knox Press.

PAGELS, E. \& KING, K.L. 2007. Reading Judas: the Gospel of Judas and the shaping of Christianity. New York: Viking.

ROBERTS, A. \& RAMBAUT, W. H., trans. \& eds. 1868. The writings of Irenaeus. Vol. 1. Edinburgh: Clark.

ROBINSON, J.M. 1977. The Nag Hammadi library in English. Leiden: Brill.

WHITACRE, R.A. 1999. John. Downers Grove: InterVarsity.

WRIGHT, N.T. 2006. Judas and the gospel of Jesus. London: Society for Promoting Christian Knowledge.

\section{Key concepts:}

betrayal of Jesus

biblical novel

Judas Iscariot

Caldwell, Taylor

\section{Kernbegrippe:}

Bybelroman

Judas Iskariot

Caldwell, Taylor

verraad teenoor Jesus 